\title{
Strategic Resources, Competitive Advantage and Firms Performance: A Research Agenda
}

\author{
Masaba George Malika ${ }^{1}$, Dr. Kilika James $(\mathrm{PhD})^{2}$ \\ ${ }^{1}$ Doctoral Candidate, Kenyatta University, School of Business \\ ${ }^{2}$ School of Business, Kenyatta University
}

\begin{abstract}
The environment in which firms operate is constantly changing and there is need for organizations to optimise the use of their resources and core competencies in order to create a sustainable competitive advantage and ensure superior performance. The general business environment has become very competitive and unpredictable thus calls for more agility amongst the organizations. Even though this relationship combined with that of innovation may lead to companies gaining competitive advantage, the previous studies have assumed a simple direct relationship and have failed to integrate other contextual characteristics of the market as espoused by some of the theoretical arguments that underpin the relationship. Sustained firm performance may result when a firm repeatedly leverages its resources and competitive advantage that service customers ever changing needs. This paper examines the direct relationship of Resources and performance while including the role of the Top Management Team and innovation .The emergent theoretical and model is proposed and various constructs and their relationship suggested.
\end{abstract}

Keywords: Strategic Resources, Competitive Advantage and Firm Performance

\section{Introduction}

Firm resources include all assets, capabilities, organizational processes, firm attributes, information, knowledge, etc. controlled by a firm that enable the firm to conceive of and implement strategies. The second part of Barney (1991) definition, namely "Strategies that improve its efficiency and effectiveness", has been dropped in order to take into account market power as well as efficiency in the creation of performance.

Different theories have also been postulated and some of the most celebrated in the arena of strategic resources, Competitive Advantage and Firms include Resource Based Approach, Porters Five Forces Theory, Resource Dependence, Theory of Dynamic Capabilities and Institutional Theory. This paper explores conceptual and empirical literature touching on Strategic Resource, Competitive Advantage and Firms Performance and seeks to establish commonalities and controversies with an overall agenda of establishing the nature of relationship between Strategic Resources, Competitive Advantage and Firms Performance.

The result of the review indicated that there was an indication to the fact that organization that optimises the use of their strategic resources and core competencies will gain competitive advantage and this leads to superior performance. This supports key postulates of the main theories.

It's also worth noting that in their contribution to the RBV, scholars have proposed various constructs, such as resources, capabilities, competencies, skills, factors and assets, to refer to different objects. The present paper uses the term 'resources' as a generic construct that encompasses all these realities.

In his analysis of the competitive environment, Porter (1980) identifies five forces: bargaining power of suppliers, bargaining power of customers, threat of new entrants, threat of substitution, and rivalry among current competitors. This list reflects Porter's adoption of a market power perspective and is ill-suited to account for the impact of the competitive environment on sustained competitive advantage and performance as this research defines them .For instance, while customers bargain for the value created by the firm (market power perspective), they also determine the value of the product through their willingness-to-pay (efficiency perspective). Despite its market power perspective, Porter's framework can be fruitfully used to analyse the competitive environment.

Peteraf and Barney (2003) defined competitive advantage as superior differentiation and/or lower costs by comparison with the marginal (breakeven) competitor in the product market. "An enterprise has a Competitive Advantage if it is able to create more economic value than the marginal (breakeven) competitor in its product market. The Economic Value created by an enterprise in the course of providing a good or service is the difference between the perceived benefits gained by the purchasers of the good and the economic cost to the enterprise" (Peteraf\& Barney, 2003).

\section{Theoretical Review}

Natural resources are resources that naturally exist in the environment, such as oil, fresh water, minerals or arable land. Natural resources cannot be created, so a firm has an advantage if it operates in a country where these resources exist. Firms can obtain natural resources, however, by entering new countries.

To be successful, firms must manage and balance all three strategic resources. It is not enough to have access to just one resource. Although some strategic resources may be more important for specific companies, they must remember to invest in other strategic resources as well. 


\section{International Journal of Science and Research (IJSR) \\ ISSN (Online): 2319-7064 \\ Index Copernicus Value (2013): 6.14 | Impact Factor (2015): 6.391}

There are various theories that have tied to explain the relationship between Strategic Resources, Competitive Advantage and Firms Performance. This paper looked into the following theories:

\subsection{Resource Based Approach)}

This is one of the main theories reviewed. The resourcebased view (RBV) emphasizes the firm's resources as the fundamental determinants of competitive advantage and performance. It adopts two assumptions in analysing sources of competitive advantage (Barney, 1991 and Peteraf\& Barney, 2003). First, this model assumes that firms within an industry (or within a strategic group) may be heterogeneous with respect to the bundle of resources that they control. Second, it assumes that resource heterogeneity may persist over time because the resources used to implement firms' strategies are not perfectly mobile across firms (i.e., some of the resources cannot be traded in factor markets and are difficult to accumulate and imitate).

\subsection{Porter's Five Forces Model}

The Porter's Five Forces tool is a simple but powerful tool for understanding where power lies in a business situation. This is useful, because it helps you understand both the strength of competitive position, and the strength of a position a firm is considering moving into. Five Forces Analysis assumes that there are five important forces that determine competitive power in a business situation. These are: Supplier Power: This factor takes into consideration how easy it is for suppliers to drive up prices. Normally, this is driven by the number of suppliers of each key input, the uniqueness of their product or service, their strength and control over you, the cost of switching from one to another, and so on. The fewer the supplier choices you have, and the more you need suppliers' help, the more powerful your suppliers are.Buyer Power: This factor takes into cognizance how easy it is for buyers to drive prices down. Again, this is driven by the number of buyers, the importance of each individual buyer to your business, the cost to them of switching from your products and services to those of someone else, and so on. If you deal with few, powerful buyers, then they are often able to dictate terms to you.Competitive Rivalry,Competitors analysis is key. The most important measure here is ' the number and capability of the competitors. If there are many competitors, and they offer equally attractive products and services, then most likely have little power in the situation, because suppliers and buyers will go elsewhere if they don't get a good deal from you. On the other hand, if no-one else can do what you do, then you can often have tremendous strength.Threat of Substitution, This is affected by the ability of your customers to find a different way of doing what you do.. If substitution is easy and substitution is viable, then this weakens a firm's power.

\subsection{Resource Dependence Theory}

The theory is important because an organisation's ability to gather, alter and exploit raw materials faster than competitors can be fundamental to success. It's concerned with how organisational behaviour is affected by external resources the organisation utilises, such as raw materials. Some commentators encourage organisations to view customers as a resource predisposed to scarcity.

The theory originated in the 1970 s with the publication of The External Control of Organizations: A Resource Dependence Perspective by Jeffrey Pfeffer and Gerald R. Salancik. RDT is underpinned by the idea that resources are key to organisational success and that access and control over resources is a basis of power. Resources are often controlled by organisations not in the control of the organisation needing them, meaning that strategies must be carefully considered in order to maintain open access to resources

\subsection{Theory of Dynamic Capability}

Dynamic capability is the capability of an organization to adapt adequately to changes that can have an impact on its functioning. The concept is defined by Teece et al. (1997) as "the firm's ability to integrate, build, and reconfigure internal and external competences to address rapidly changing environments." The term is often used in the plural form, dynamic capabilities, emphasizing that the ability to react adequately and timely to external changes requires a combination of multiple capabilities.

The term Dynamic Capabilities was first introduced in a working paper in 1989, was influenced by Gary Hamel's multinational strategy research leading to Core Competences of the Corporatio and was cited in IkujiroNonaka and Hirotaka Takeuchi's innovation strategy work The Knowledge-Creating Company. Originally, dynamic capabilities was distinct from operational capabilities, which pertain to the current operations of an organization. Dynamic capabilities, by contrast, refer to "the capacity of an organization to purposefully create, extend, or modify its resource base" (Helfat et al., 2007).

\subsection{Institutional Theory}

Institutional theory refers to "A widely accepted theoretical posture that emphasizes rational myths, isomorphism, and legitimacy." Institutional theory focuses on the deeper and more resilient aspects of social structure. It considers the processes by which structures, including schemes, rules, norms, and routines, become established as authoritative guidelines for social behaviour (Scott, 2004). Different components of institutional theory explain how these elements are created, diffused, adopted, and adapted over space and time; and how they fall into decline and disuse.

There is no single and universally agreed definition of an 'institution' in the institutional school of thought... Scott (1995) asserts that "Institutions are social structures that have attained a high degree of resilience. They are composed of cultural-cognitive, normative, and regulative elements that, together with associated activities and resources, provide stability and meaning to social life. Institutions are transmitted by various types of carriers, including symbolic systems, relational systems, routines, and artefacts. Institutions operate at different levels of jurisdiction, from the world system to localized interpersonal relationships. 


\section{International Journal of Science and Research (IJSR) \\ ISSN (Online): 2319-7064 \\ Index Copernicus Value (2013): 6.14 | Impact Factor (2015): 6.391}

Institutions by definition connote stability but are subject to change processes, both incremental and discontinuous

\subsection{Competitive Dynamics}

The competitive dynamics perspective focuses on actionsspecifically, on the series of actions (and reactions) firms initiate to enhance their competitive position and improve performance. Thus, the competitive dynamics view posits that a firm's actions and its reactions to rivals' actions determine its performance outcomes (Smith et al., 2001). Moreover, instead of investigating a single action, considering the repertoire of a firm's actions is also a strong point of interest in this research (Ferrier, 2001).

The theoretical foundation of the competitive dynamics literature is the 'awareness-motivation-capability model' (where capability refers to firm resources) (Chen, 1996). Awareness' refers to the mindfulness of managers about their competitive context, which includes competitors, industry, and the general environment (Smith et al., 2001). Factors that have been shown to influence managers' awareness of their competitive environment include firm size (Chen \&Hambrick, 1995), scale of operations (Chen et al., 2007), market diversity (Miller \& Chen,1996), and top management team characteristics (Hambrick, Cho, and Chen, 1996). Motivationrefers the incentive to engage in competitive activity, either proactively or reactively. Prior research has linked past performance, market dependence (Chen, 1996), and competitor activity (Ferrier, 2001) to the motivation to engage in competitive activity.

\subsection{Empirical Findings on Previous Research Conducted on the Concept.}

Numerous studies have set out to examine the relationship between strategic resources and firm performance. The traditional VRIO attributes have been the point of departure in most resource-based studies. This paper sets out to argue

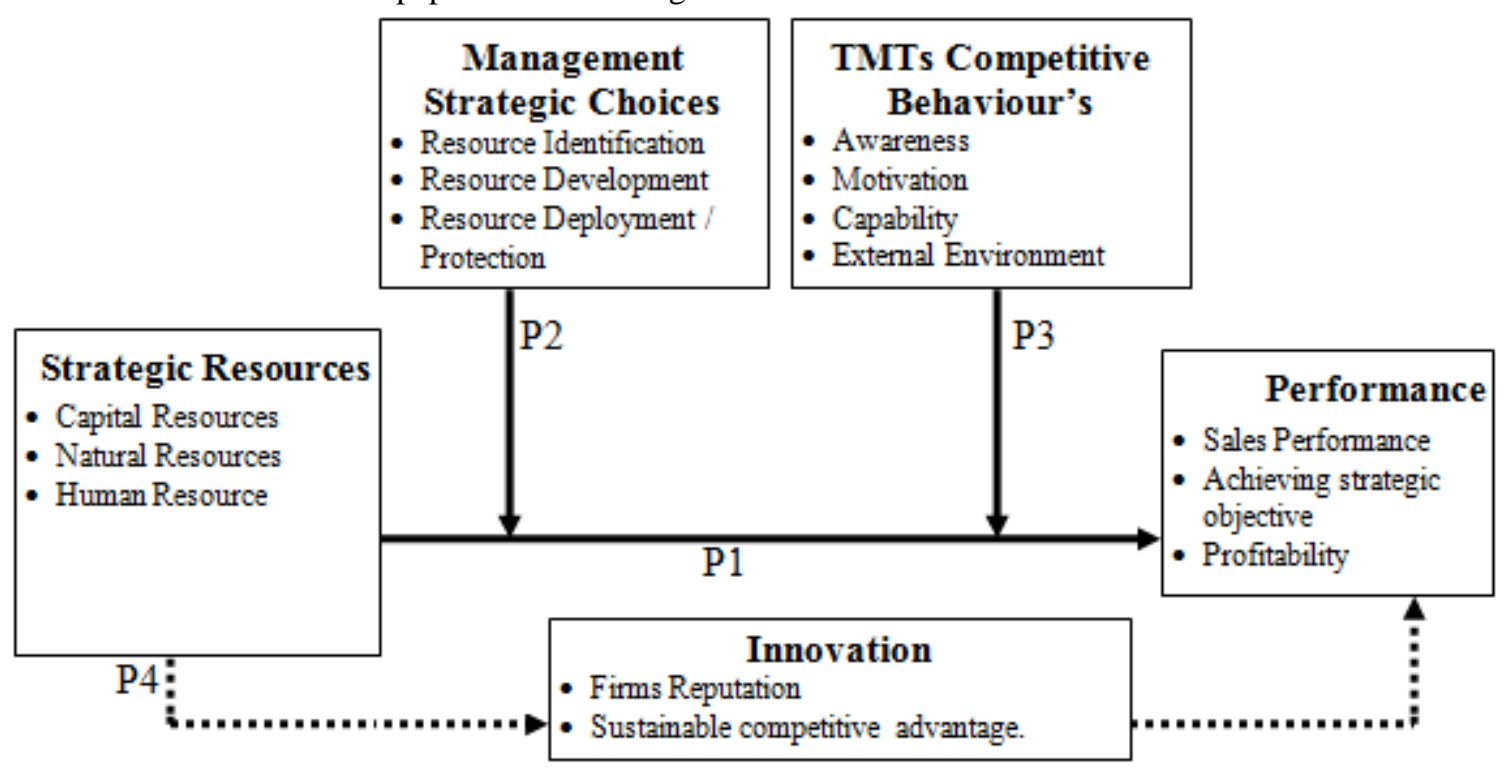

(Source: Author 2016)

\subsection{Construct and Propositions}

The construct and propositions are discussed as below. that the relationship between resources and performance is more complex. Anderse'n(2013) undertook this study to illustrate the complex relationship between a strategic resource and firm performance by providing an overview of different factors that can influence this relationship. It was found that five criteria must be fulfilled for resources to generate superior Performance. These are identified and discussed. These criteria fit with existing resources, management capability, marketing capability, firm appropriation of rent, and non-competitive disadvantages. The limitation identified was that by using the criteria identified, resource-based theory can become less tautological. Also, the criteria highlight the importance of resource utilization and appropriation of resource-based rents

Luliya, Sununta, Badir and Chotchai, (2012) undertook a study on Competitive strategies and firm performance: the mediating role of performance measurement. The study found that generally, all competitive strategies positively and significantly enhance firm performance through performance measurement. Specifically, firms' differentiation strategy not only has a direct and significant impact on firm performance but also it has indirect and significant impact on firm performance through financial measures

Yuttakorn (2013) studied sources of sustainable competitive advantage: the case of rice-milling firms in Thailand. Results from a survey of rice mills involved in international export showed that Organizational reputation, some HRM practices, and networks were significantly related to firm's performance, but vertical integration was not. This study supports the basic assertion of RBV theory that a set of firm specific resources could be applied in ways that enhance sustainable competitive advantage.

\subsection{Conceptual Framework}

\section{ITs Competitive Behaviour's \\ Awarenes \\ - Capability \\ - External Environment}

\section{Volume 5 Issue 6, June 2016 www.ijsr.net}




\section{International Journal of Science and Research (IJSR) \\ ISSN (Online): 2319-7064 \\ Index Copernicus Value (2013): 6.14 | Impact Factor (2015): 6.391}

capabilities, and leverage thosecapabilities to create value (Sirmon et al., 2007.Firms which have strategic resources that are Valuable, Rare, Inimitable and the organization has the capability to organise it can gain sustainable competitive advantage and increase performance.

\subsubsection{Strategic Choices}

Strategic choice is central to strategy making. An effective strategic choice process positions an organization for making sustainable strategic decisions. At the heart of effective strategic planning lies the ability to surface the truly important issues and to make good choices, in the process of deciding how to address these issues.

Firms with Management teams that make sound strategic decision will have superior performance.

\subsubsection{Competitive Behaviour}

There are various drivers of Competitive Behavior's:Awareness, Motivation, Capability, External Environment.

Firms that have management teams TMT that are aware about the changes in the environment, Motivated, are capable to handle difficult and different situations will have superior performance.

\subsubsection{Innovation and Sustainable Competitive Advantage}

Competitive advantage exists when a particular company consistently outperforms other companies in the same industry. Organizations that stay ahead in terms of innovation will definitely be considered to be outperforming others if profits are higher than the competition's profits. The competitive advantage is thought to be stronger when it lasts for a longer period of time. Those companies who are able to maintain a competitive advantage for many years are thought to have a sustainable competitive advantage.Innovative Firms with good reputation in the market will gain sustainable competitive advantage will definitely have superior performance

\section{Conclusion and Recommendations}

This was a desktop review and the researcher reviewed literature to identify the evolution, key concepts and the empirical literature available on the concept of Strategic Resource, Competitive Advantage and Firms Performance while identifying gaps in research. Based on the identified gaps, the researcher proposes to carry out further researchThis paper has taken a deep look into strategic resources, Competitive Advantage and Firms Performance. Several theories have been reviewed; RBV Model, Potters Five Forces, Theory of Dynamic Capabilities, Resource dependency theory and institutional theory. Also reviewed were relevant journals. A theoretical Framework has been proposed which can enable a firm gain sustainable competitive advantage and superior performance.

The result of the review indicated that there was an indication to the fact that organization that optimises the use of their strategic resources and core competencies will gain competitive advantage and this leads to superior performance. This supports key postulates of the main theories. There are commonalities of thought as to the effects of Strategic Resources, Competitive Advantage and
Firms Performance. Indeed, such a thread of thought runs through leaving little doubt as to the seemingly positive relationship between the three in the dynamic business environment.

However the study recommends that an in-depth study of the Influence of strategic resources, distinct competences on firms performance. The moderation effect of the Top Management Team (TMTs) in the day to day running of the business should be also studied. Also, study to analyse of the effect of the drivers of competitive behaviour in organizations affect performance will enable management to understand the impact of their decision and the organization culture to the performance. Finally, the Mediation effect of innovations and firms reputation can be looked at and how this affects the performance of the firm

\section{References}

[1] Acedo, F.J., Barroso, C. and Galan, J.L. (2006): "The resource-based theory: Dissemination main trends", Strategic Management Journal, 27(7), 621-636

[2] Alvarez, S.A. and Busenitz, L.W. (2001): "The entrepreneurship of resource-based theory", Journal of Management, 27(6), 755 -775

[3] Amit, R. and Schoemaker, P.J.H. (1993): "Strategic assets and organizational rent", Strategic Management Journal, 14(1), 33 - 46

[4] Anderse'n, J. (2007): “A holistic approach to acquisition of strategic resources", Journal of European Industrial Training, 31(8), 660 - 677

[5] Anderse'n, J. (2007): "How and what to imitate? A sequential model for the imitation of competitive advantages", Strategic Change Journal, 16(6), 271 279

[6] Aosa, E. (2009):" The Leadership Challenge Facing Kenyan Organizations", The Account Journal of The institute of Certified Public Accountant of Kenya

[7] Barney, J.B. (1991): "Firm resources and sustained competitive advantage", Journal of Management, 17(1), 99 - 120

[8] Barney, J.B. (1994): "Bringing managers back in: a resource-based analysis of the role of Managers in creating and sustaining competitive advantages for firms"

[9] Barney, J.B (2012): “Organizational culture: can it be a source of sustained competitive advantage?" Academy of Management Review.11(3), 656-665

[10] Barney, J.B. and Hesterly, W.S. (2008), Strategic Management and Competitive Advantage: Concepts and Cases, Pearson/Prentice-Hall, Upper Saddle River, NJ.

[11] Barney, J.B., Wright, M. and Ketchen, D.J. Jr (2001): "The resource-based view of the firm: ten years after 1991", Journal of Management,27(6), 625-641

[12] Collis, D.J., Montgomery, C.A. (2005): "Competing in resources: strategy in the 1990s", Harvard Business Review, 73(4), 118-128

[13] Day, GS, Wensley, R (2008):" Assessing Advantage: A Framework for Diagnosing Competitive Superiority", Journal of Marketing

[14] Dess, G.G., Davis, P.S. (2009): "Porter"es (1980) generic strategies as determinants of strategic group

\section{Volume 5 Issue 6, June 2016}




\section{International Journal of Science and Research (IJSR) \\ ISSN (Online): 2319-7064}

Index Copernicus Value (2013): 6.14 | Impact Factor (2015): 6.391

membership and organizational performance", Academy of Management Journal, 27(3), 467-488

[15] Dixit, A. K., \&Nalebuff, B. J. (1991): Thinking Strategically. New York: Free Press.

[16] Eisenhardt, K.M. and J.A. Martin, (2010):'Dynamic capabilities: What are they?" Strategic Management Journal, 21(2), 1105-1121

[17] Faulkner, D. O., \& Campbell, A. (Eds.). (2003). The Oxford Handbook of Strategy, 2(3), 38-46

[18] Grant, R.M., (2010) The Resource-based Theory of Competitive Advantage: Implications for Strategy Formulation, California

[19] Hunt, D, RM Morgan (2005): "The Comparative Advantage Theory of Competition" Journal of Marketing, 2(3), 55-58

[20] Macmillan, H., \&Tampoe, M. (2000): Strategic Management - process, content, and implementation. London: Oxford University Press

[21] Pearce, J.A and Robinson, R. (2007): Strategic Management:- Strategic Formulation and Implementation. Richard D. Irwin Inc. U.S.A., 3rd Edition.

[22] Porter, M. (1980): Competitive Strategy: Techniques for Analysing Industries and Competitors, Free Press, New York

[23] Porter M.E., (2010); Competitive Strategy: Techniques for Analyzing Industries and Competitors, Free Press, New York,

[24] Porter, M.E (2011): "Towards a dynamic theory of strategy", Strategic Management Journal, 12(1), 95 117

[25] Porter, M.E (2008):" What is strategy?" Harvard Business Review, 74(6), 61 - 78

[26] Porter, M.E (2010):" Strategy and the Internet”, Harvard Business Review, 62(2), 35 - 45

[27] Prahalad C.K., Hamel G., (2010):" Core Competency Concept", Harvard Business Review, 59(3), 62 - 78

[28] Prescott, J.E. (2011): The evolution of competitive intelligence, in Hussey, D.E. (Ed.), International Review of Strategic Management, Wiley, Chichester. NY,

[29] Prescott, J.E. and Bhardwaj, G. (2005):" Competitive intelligence practices: a survey", Competitive Intelligence Review, 7(1), 41-48

[30] Prescott, J.E. and Gibbons, P.T. (2006):"The seven seas of global competitive intelligence", Competitive Intelligence Review, 62(1), 98-103

[31] Rainbird, M. (2010):"A framework for operations management: the value chain", International Journal of Physical Distribution and Logistics Management, 34(2), 12-25

[32] Johnson, G., Scholes, K., \& Whittington, R. (2005): Exploring Corporate Strategy. Harlow: Prentice Hall. 